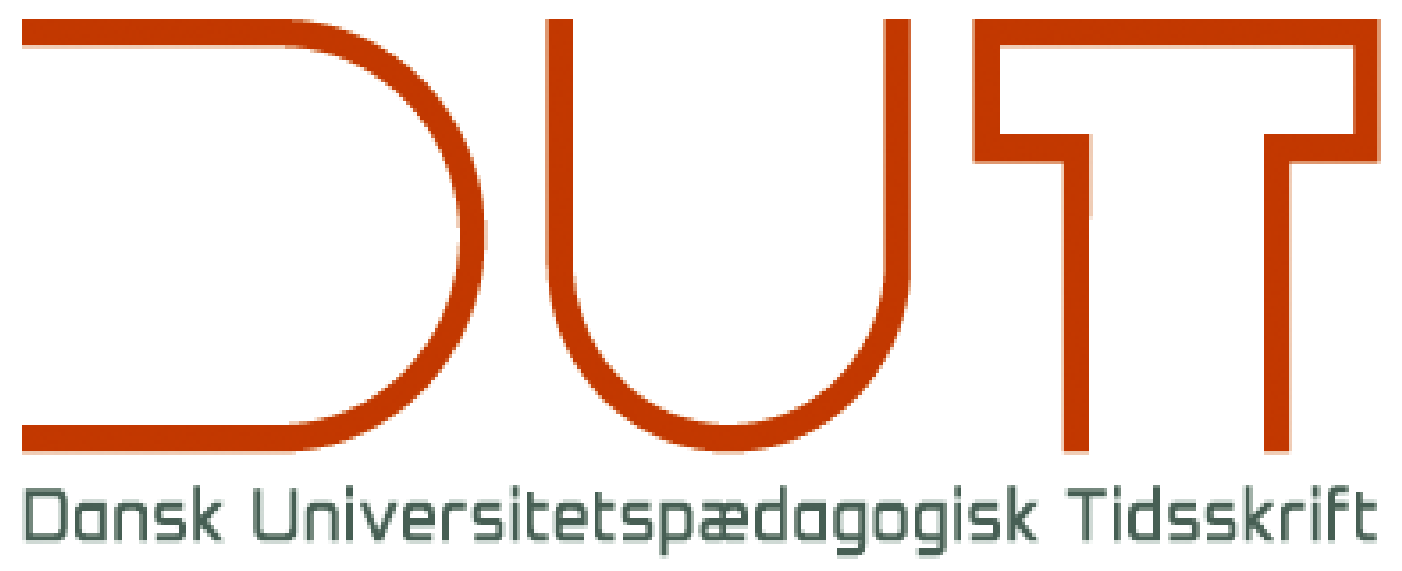

Tema

Fra data til beslutninger

Årgang 14 nr. 26 / 2019

Titel

DUT Guide on teaching and learning in the international classroom

Forfattere

Karen M. Lauridsen

Sidetal

$125-132$

Udgivet af

Dansk Universitetspædagogisk Netværk, DUN

URL

> http://dun-net.dk/

Betingelser for brug af denne artikel

(C) Copyright
Denne artikel er omfattet af ophavsretsloven, og der må citeres fra den. Følgende betingelser skal dog være opfyldt:

- Citatet skal være i overensstemmelse med "god skik"

- Der må kun citeres „i det omfang, som betinges af formålet“

- Ophavsmanden til teksten skal krediteres, og kilden skal angives ift. ovenstående bibliografiske oplysninger.

DUT og artiklens forfatter 


\section{DUT Guide on teaching and learning in the international classroom}

Karen M. Lauridsen ${ }^{\mathrm{a}, 1}$

${ }^{a}$ Centre for Teaching and Learning, Aarhus University

This DUT Guide offers seven pieces of good advice for those teaching international programmes to diverse student audiences. In essence, the advice is all about being a good lecturer in a higher education context, so the points addressed here are primarily the additional factors that are important to keep in mind when the programme content is internationalised, and the students have different educational, cultural, and linguistic backgrounds.

1. Assess your higher education environment.

2. Assess and adjust the international and intercultural components of your course.

3. Discover and respect the disciplinary, cultural, and linguistic diversity among your students.

4. Consider your students' learning needs.

5. Scaffold your students' learning: Focus on strengths and alleviate weaknesses.

6. Be explicit in your communication and behaviour.

7. Consider the group dynamics: Turn challenges into opportunities.

\section{Background}

The international classroom and international programmes are cover terms that may reflect a range of different realities across higher education institutions (HEIs). They are often used interchangeably to cover the students' diverse educational, cultural, and linguistic backgrounds, the content of the course or programme, the language of instruction (in Denmark often English), or a combination of all of these factors. They are rarely used to indicate specific ways of teaching in the classroom, even though many lecturers encounter educational, cultural, and linguistic challenges that have implications for how successful they are when teaching such programmes.

In the following, it is assumed that the international classroom reflects the diversity of the student cohort, but also that it is a learning space in which the HEls seek to establish what is known as Internationalisation at Home:

\footnotetext{
${ }^{1}$ Contact: kml@au.dk
} 
Internationalization at Home is the purposeful integration of international and intercultural dimensions into the formal and informal curriculum for all students within domestic learning environments. (Beelen \& Jones, 2015:69)

Internationalisation at home is part of the internationalisation of higher education (de Wit et al., 2015) and of the internationalisation of the curriculum (Leask, 2015).

Within this conceptual framework, the terms international classroom and internationalised programmes ideally cover the following:

- A curriculum content that, depending on the discipline, includes examples from different cultures or geographical areas, or comparisons across such cultures and areas. Examples of this would be not only teaching the political system in a given country, but comparing it with other systems in other countries (political science); understanding and comparing issues related to caring for the terminally ill in different cultures (medicine or nursing); or an interdisciplinary programme or course on clean water supply in different parts of the world.

- A set of intended learning outcomes that reflect such international and intercultural components, including the development of students' intercultural competences and leading to a set of graduate attributes for the programme as a whole. An example would be that the successful graduate has demonstrated the ability to lead and manage multicultural teams within the disciplinary context (e.g. engineering).

- A programme taught in a language that may or may not be the local or national language of the higher education institution. The obvious example in a Western European context is English Medium Instruction (EMI), which does not in itself make a programme international, but may be one characteristic of an international programme; such a programme may also be taught in the local (national) language, however.

- A programme taught to a diverse group of students. In addition to general demographic differences, race, gender, beliefs, etc., the students may come from different educational backgrounds (disciplines or national systems) and have different first languages and cultures. They may be mobile (international) students, or they may be local. Whether mobile or local, all students come together and learn from and with each other.

These characteristics of international programmes have implications for how they are taught. The advice offered below may be considered good academic practice in any classroom and is therefore always important to keep in mind; but the points made become even more crucial in an international classroom with diverse student cohorts.

Research on how to turn the principles of the conceptual underpinnings into academic practice is still an emerging field. The advice offered below is inspired by and developed from Leask and Carroll's Good Practice Principles (Carroll, 2015; Leask \& Carroll, 2013); the IntlUni Project (Lauridsen \& Cozart, 2015; Lauridsen \& Lillemose, 2015), and the EQUiiP Project (forthcoming). 


\section{Tip 1}

\section{Assess your higher education environment}

In Europe, most HEls will have policies in place for the internationalisation of research and education. The question is how these policies and strategies are transformed into the academic practice of the international classroom. How conducive is the institutional environment to international programmes as outlined above? Does the HEI leadership and management team consider the number of programmes taught through English and the number of mobile students as the main indicators of the level of internationalisation, or are there in fact measures in place that seek to develop the international and intercultural components of the educational programme and of the study experience for all students? The answers to these questions determine the agency that you as a lecturer will have for teaching international programmes and navigating international classrooms.

\section{Tip 2}

\section{Assess and adjust the international and intercultural components of your course}

Let us take Danish higher education as an example. In order to attract a substantial number of non-Danish students, a programme or course would typically be taught through English. So when you develop your EMI course, or when you take over responsibility for a course developed by someone else, you would be well advised to start by ascertaining whether internationalised learning outcomes and graduate attributes have been defined. If not, the course description may just be a translation into English of an existing course that has been taught through Danish. If that is the case, you will need to decide whether or not you want to work with the powers that be and change the course description.

Whatever you choose to do will have implications for the content of the course and how you teach it. Experience tells us that, more often than not, students' motivation for learning in a multicultural environment and engaging in interaction with peers who have a different background than they do themselves, is determined by the extent to which this interaction is a requirement and an integrated part of the course and programme.

A course description with internationalised learning outcomes would be most conducive to intercultural learning and group dynamics. Examples of international and intercultural disciplinary content have already been given in the introduction above. Just as important is the way such content is taught. Let us consider an example.

It is important to recognise the resources in the classroom - whether in a large lecture hall or a small class setting. All students have prior knowledge and experience which may be leveraged in the classroom to the benefit of all students. Imagine a course in business management. Leadership hierarchies differ considerably between cultures, some of them high and complex, others flat and with more agency and responsibility for the individual employee. From the outset, students would tend to think that leadership hierarchies are similar everywhere; they would therefore not be aware of the vast differences that may be observed even between cultures that are otherwise relatively close to each other. When discussing a business case, the lecturer may invite students to suggest solutions that would work in their respective home cultures, thereby demonstrating the cultural differences to all students in the classroom. The lecturer must obviously encourage students from diverse backgrounds to come forward and explain their culture-specific solutions to the business case in order for all 
the students to have a richer learning experience as a result of working with it.

When a lecturer decides to make all students' tacit knowledge on a given topic more explicit to everyone in the classroom, it has implications for how s/he plans the teaching sessions. In a large lecture hall, it may be something as simple as using questions in an electronic student response system to spark short pair or peer discussions as an activity during the lecture. In a small class setting, it will have implications for how student engagement in peer groups is organised and managed.

\section{Tip 3}

\section{Discover and respect the disciplinary, cultural, and linguistic diversity among your students}

Part of your course planning is also knowing for whom you are planning the course. You will need to have an idea of the diversity among your students and reflect on how you can take that into consideration when you plan and teach your course.

Your students may have different disciplinary backgrounds: If you are teaching a course that attracts students from different disciplines, you will want to know which disciplines they come from and how you can leverage their diverse knowledge and skills for the benefit of all students in the classroom. You may, for instance, design a group task that can only be solved if students draw on their different content knowledge, different research methodology skills (statistics, production or analysis of quantitative or qualitative data), or whatever is appropriate within the context of your course or discipline. With a clear purpose, the task becomes meaningful in context for the students, and they learn to appreciate their differences as strengths in the task-solving process.

Your students may have different educational backgrounds: Some of your students may be used to an educational culture where most or all teaching takes the form of lectures where students are expected to listen and take notes in order to regurgitate what they have heard at the exams. Others, like most Danish students, will be used to an educational culture where students are expected to be actively engaged in peer collaboration in and between classes. If you expect your students to be actively engaged, you will need to consider how you will introduce this to and manage this with students from other educational backgrounds. One possibility here would be to design student collaboration so that all students in a group have clear roles and so that - in the course of the academic term - they all try the different roles at least once. Such roles could be as experts of a specific aspect of the disciplinary content or in specific methods (see the examples in the previous paragraph); it could be as note-taker and the one responsible for uploading a summary of outcomes in a blog or other medium on the learning management platform, as moderator of discussions in the group, or as presenter in the large group on behalf of the peer group, etc. If you explain from the beginning what this entails and why you do it, all students will benefit from working with each other and - again learn to appreciate the differences among them.

Your students may have different cultural backgrounds: In addition to what has already been mentioned, your students may have different religions and beliefs, or come from cultures or countries that are or have been at odds or at war with each other. In most cases you would not need to take this into consideration in your teaching, but there may be instances when it would be most respectful to do so, or instances when you can grasp the opportunity to make it a learning moment for all. For instance, in a history class, you may have students present 
the same historical events from different cultural (national, regional, etc.) perspectives before you discuss the similarities and differences among these perspectives with them; this will help them appreciate that there is not one historical truth. One possibility would be to have students present from the perspective of their home culture, another is to make sure that all students present from a perspective that is not their own. Similar activities could be framed within different theories or schools of thought, different political parties, etc.

Your students may have different linguistic backgrounds: Many of the students will not have the language of instruction as their first language. While this may create challenges for them (see also under tip 4 below), you may exploit the fact that many of them will be able to read disciplinary literature in another language. This may be helpful in activities such as those mentioned in the previous paragraph above, but it may in fact also be an asset in a number of other types of individual or group assignments. The only thing is that the lecturer should be brave enough to let students use electronic or printed sources that s/he cannot check because s/he does not master all the languages present in the international classroom.

So the question remains how you obtain the information needed to take all these differences into account in the planning and teaching of your course. The most obvious solution is to consider which differences you would like to leverage in a particular course and then have the students fill in a short, targeted survey (e.g. on the learning management platform) just before or at the beginning of the course.

\section{Tip 4}

\section{Consider your students' learning needs}

Tip 3 above focused on how you may leverage the differences in your student cohort and create learning moments for them all. There is obviously a flipside to this coin. The differences among them may also mean that some students have learning needs that must be addressed if they are to successfully complete your course. Again, this may pertain to disciplinary content, methodologies, skills or language, and you will need to reflect on how you can assist your students in the process in a meaningful way (and without going way beyond the time you have been allotted for the course). What follows here assumes that the students have been screened appropriately (during the application and registration process) so that, generally speaking, they master the prerequisites for the programme or course.

If there is some disciplinary content that they need to cover or recapitulate, you may refer them to some supplementary literature if this need is not alleviated by working together in peer groups - or even if it is. When doing so, you should be mindful of the fact that the students in question will need to read this supplementary literature in a foreign language, and that this often takes extra time. So, if possible, it would be a good idea to (also) refer the students to literature in their own language.

As for methodologies, much can be learned by working with peers in the course of the academic term, but here supplementary reading may also be necessary. Whether or not students are already familiar with a given methodology, you should always make sure that they are given the opportunity to work with it in the course of the academic term so that they are prepared to do so when their work is assessed during or at the end of the academic term. The same applies to any skills, the mastery of which students have to demonstrate when their work is assessed. Practice makes perfect! 
Finally, the language component. All students may struggle with academic reading and writing, even in their first languages, and academic literacy and academic writing are skills that must be learned - and therefore also taught - in any programme. In addition to that, some students may have language issues even though they have passed the language tests and demonstrated the minimum level of language proficiency required for a specific programme or course. If that is the case, it is important that you as the lecturer know where students can improve their language skills. In Denmark, most HEls do not have a language centre for such purposes, which makes it even more important that all students master the language of instruction to a sufficient level before the beginning of the course.

\section{Tip 5}

\section{Scaffold your students' learning: Focus on strengths and alleviate weaknesses}

Following directly from tips 3 and 4 above, it is important that you scaffold your students' learning. Help them appreciate their strengths and leverage them as indicated under tip 3, and help them alleviate their weaknesses by addressing their learning needs as indicated under tip 4. However, even if you do that, your students would still benefit from a robust structure (scaffold) to guide them through the course and support their learning. Again, such scaffolding may take different forms depending on the discipline or course, but an obvious example would be to provide support materials or develop them in collaboration with the students.

\section{Tip 6}

\section{Be explicit in your communication and behaviour}

As already indicated in the above sections, students come with diverse prior knowledge and experience, and you can in fact not take anything for granted. While students may learn from each other in peer groups, it is still very important that you as the lecturer are very explicit in your communication and behaviour. You must tell the students exactly what is expected of them in the course of the semester and at the exams; you must also give them the opportunity to try it out while they are still learning - write in the specific genre that is required, use specific technology as required, take on roles in peer interaction, etc. Be aware that some students may be uncomfortable with your direct communication as they will be used to a much more indirect form of communication in their home cultures. If/when you observe that that is the case, take a moment to explain and discuss this with the students and help them overcome their uneasiness.

\section{Tip 7}

\section{Consider the group dynamics: Turn challenges into opportunities}

There will be times when students - mobile and local - are challenged in the international classroom. Individual students or peer groups may encounter situations where their differences seem to become a barrier for them to move forward in their learning process. When you observe such a situation, you cannot ignore it. It does not just go away. You will have to stop your lecture or small class procedures and seize the opportunity to resolve the issue. If you do that and help the students resolve a (potential) conflict, you also help them learn disciplinary content at the same time as they develop their intercultural competences. The issue turns into a learning moment for them. 


\section{Conclusion}

It is especially important to keep group diversity and the group dynamics in mind when teaching in the international classroom. Your students are all learning - not only disciplinary content, but also peer group interaction. If you pay attention to it, plan your teaching accordingly, and address issues as they arise, you also help your students develop their intercultural competences, which will be valuable graduate attributes when they start their professional careers.

Two points will have become apparent in the sections above: The seven tips reflect what we would consider good teaching in any context, and they are interlinked and overlap to a certain extent. This is very much on purpose and also unavoidable. It is all higher education teaching and learning, irrespective of the characteristics of the student target group. The aim of this short DUT Guide has been to make the reader aware of some of the factors that are specific characteristics of the international classroom, and which the lecturer would be well advised to address when teaching international programmes to diverse student audiences.

\section{References}

Beelen, J. \& E. Jones. 2015, "Redefining Internationalization at Home”, in Curaj, A., L. Matei, R. Pricopie, J. Salmi \& P. Scott (Eds), The European Higher Education Area. Between critical reflections and future policies. Springer.

Carroll, J. 2015, Tools for Teaching in an Educationally Mobile World, Internationalization in Higher Education Series, Routledge.

De Wit, H.; F. Hunter; L. Howard; E. Egron-Polak. 2015, “Internationalisation of Higher Education", Study requested by the European Parliament's Committee on Culture and Education, available at:

http://www.europarl.europa.eu/RegData/etudes/STUD/2015/540370/IPOL STU(2015) 540370 EN.pdf

EQUiiP. Forthcoming/2019, “Educational Quality at Universities for inclusive international Programmes", available at: http://www.EQUiiP.eu.

IntlUni. 2015, "The Challenges of the Multilingual and Multicultural Learning Space", available at: http://www.IntlUni.eu.

Jones, E. 2017, "Problematising and reimagining the notion of the 'international student experience", Studies in Higher Education, 42.5.

Lauridsen, K.M. \& S.M. Cozart. 2015, “Teaching and Learning in the international classroom: quality principles and lessons learned from the IntlUni project", in Internationalisation of Higher Education. An EAIE Handbook, 2015,3. Raabe.

Lauridsen, K.M. \& Lillemose, M. K. (Eds). 2015, Opportunities and challenges in the multilingual and multicultural learning space, Final document of the IntlUni Erasmus Academic Network 2012-15, available at: http://intluni.eu/uploads/media/The_opportunities_and_challenges_of the_MMLS_Fin al report sept 2015.pdf 
Leask, B. 2015, Internationalizing the Curriculum, Internationalization in Higher Education Series. Routledge.

Leask, B. \& Carroll, J. 2013. Learning and Teaching Across Cultures. Good Practice Principles and Quick Guides, available at: http://www.ieaa.org.au/documents/item/397 